\title{
ICT solutions in \\ intelligent organizations as challenges in a knowledge economy
}

Piotr Adamczewski, Ph. D. WSB University in Poznań Institute of Management

\section{Introduction}

The development of information processing technologies is strongly correlated to new tools of the management process support. The operation of modern organizations within the global economy necessitates the adaptation of management methods and development strategies to new business conditions at the stage of digital transformation, which is gaining momentum at present. In terms of the development of digital services in the private sector, personnel competences, and e-government quality Poland ranks only 28th out of $30 \mathrm{EU}$ countries. The good news is the fact that we are among the global economies which are undergoing the fastest digitalization (4th position out of 30 surveyed countries) (Report Czas na przyspieszenie 2016, p. 15). It is less reassuring that Poland is the last but three countries in Europe in terms of using ICT solutions in all economy sectors. It has obtained 33 points in the Economy Digitization Index, i.e. half of the score of Norway, the leader of the ranking. We are still behind other countries in terms of used hardware, software, and sale of e-services. The situation certainly varies among economy 
sectors; for example, the Polish financial sector is relatively well digitized (9th place in Europe), which results from the strong competition on the market and the friendly regulatory policy. However, the general conclusion of the report is that major effort is necessary for Poland not to be at the end of rate. According to the forecast of IDC, until the end of 2017 more almost 70\% companies from the list of largest global firms will place the digital transformation in the centre of their corporate strategies. IDC predicts the spread of digital transformation and the mass application of the so-called third ICT platform (Report IDC 2016, p. 22).

The dynamic development of ICTs in recent years has popularised the third platform, which is also described as SMAC (Social, Mobile, Analytics, Cloud). It creates a unique eco-system of IT solutions that enables organizations to develop their businesses at lower financial costs and with maximum reach. The constantly growing quantity of data provided by mobile devices, social media, browsers, and loyalty programmes, is creating a new business model based on information generated by the business environment. The proper processing of such information is the condition necessary for achieving a success in business.

This article is aimed at showing the nature and the growing importance of the third platform in the digital transformation of business organizations. This paper discusses how to deploy advanced SMAC-system in Polish intelligent organizations. The study encompassed the representative sample of 100 enterprises from the SME sector from Mazowieckie and Wielkopolskierovinces. According to research by Cisco Global Cloud Index, in 2018 half of the global population will have Internet access, with more than $53 \%$ people using tools for data storage in a cloud with mobile devices (Cisco Global 2014, p. 45).

\section{The essence of intelligent organizations}

An intelligent organization is the one, which rests its operation philosophy on knowledge management. This term was popularized in the 1990s due to growing development of ICT, dynamically changing economic surroundings and the growth in market competition. An intelligent organization is a learning organization, with the capacity for creating, gaining, organizing and sharing knowledge and using the knowledge for the purpose of increasing the operational effectiveness and competitiveness on the global market. The idea of such an organization is founded on the system approach to the organization, namely treating it as a complex organism based on existing structures and implemented processes, with particular emphasis on the role of knowledge. In this approach - called the "fifth discipline" - owing to knowledge and relevant tools, all 
components of the organization and its staff are able to cooperate skillfully to implement defined objectives. By this, the whole organization operates as an intelligent, well-functioning organism in competitive surroundings. It clarifies mutual relations between the goal-achieving methods and their comprehension, problem-solving methods and internal as well as external communication.

The most important attributes characterizing intelligent organizations include, among others (Grösser 2012, p. 250; Quinn 2002, p. 45; Schwaninger 2010, p. 7; Waltz 2003, p. 36):

- pace and flexibility of operation,

- the ability to observe the environment,

- the ability to diagnose market signals early and react to changes in the environment,

- the ability to implement new, knowledge-based solutions in a quick manner and, owing to this, achieve economic benefits.

The growing volume of information used in an intelligent organization increases its significance. Traditional production factors: land, labour and capital are losing importance to the benefit of the key resource, which in creative functioning of the organization is the knowledge; it stands for intangible resources associated with human action, the application of which may be the grounds for gaining competitive advantage. Knowledge may be treated as information placed in organizational context and the ability of its effective use in the organization's operation. This means that knowledge resources comprise data on customers, products, processes, environment etc. in a formalized form (documents, databases) and non-codified (the employees' knowledge).

In practical terms the effective co-dependency of these elements means the necessity of the use of advanced ICT solutions within the framework of economic organization's ICT system. It uses technical, technological and organizational innovations appearing over the recent years. They comprise nearly all areas of logistic activity, from the development of the means of transport and equipment, through the organization and management of material and raw material flow to the development of structures of systems performing logistics processes. The area of their operation is the implementation of virtual processes in the environment of extensive ICT networks (most frequently the Internet is the technological platform) aimed at the coordination and integration of business partners in the supply chain.

\section{ICT solutions in intelligent organizations}


An intelligent organization as an economic system that uses advanced ICT infrastructure in its internal organization and also external communications is the modern core of the information society operating in business areas. In practice, it means the support of ICT for the basic organizational structures and the implementation of the now economy concept in the on-line mode involving (Adamczewski 2015, p. 17; Koronios 2010, p. 88; Model biznesu 2013, p. 44):

- the level of technical infrastructure (hardware),

- the level of system-communication infrastructure,

- the level of application software,

- the level of integrating business processes with external counterparties.

The dynamic advancement of ICT has led to the development of a new technological standard, namely SMAC systems, which make it possible to implement new business models. They are based on four pillars (Vongsingthong, Smanchat 2014, p. 47):

1. Social - social media remove barriers in the information flow among people and become platforms that enable the fast exchange of knowledge, which is becoming more and more effective. Communication within social media is strongly displacing telephone and e-mail communication. This phenomenon is also taking place in business, where the fast exchange of information is essential. The use of social media makes it possible to gain better interaction with customers, which facilitates faster reactions to problems and building the knowledge base according to user preferences and behaviour. Employees may meet in the social media to exchange their experiences and interesting content much faster and quicker, thus accelerating the resolution of problems.

2. Mobile - mobile devices such as smartphones and tablets have become an indispensable part of our lives. They have also opened up new opportunities of reaching customers who use mobile devices and have become accustomed to shopping and using different types of services and applications regardless of time and place. The growing popularity of mobile services has also forced entrepreneurs to develop their e-marketing and to provide customers with mobile channels. In such conditions, the presentation of an offer of mobile devices is the foundation for gaining and maintaining a strong market position.

3. Analytics - the understanding of behaviour and preferences of customers is among the greatest advantages that comes with using analytical tools. The collected data analysed with advanced algorithms can be used by entrepreneurs to understand how to earn loyalty of their customers, enhance marketing campaigns, improve product development processes, and render 
services that meet preferences and requirements of their customers. By learning preferences of users, entrepreneurs can present content that meets their expectations. Therefore, the key objective in using analytical tools in business is to take right decisions according to updated and aggregated information.

4. Cloud - the cloud computing technology offers tools that enable to collect information effectively and manage a business efficiently. By using tools available in a cloud organizations are able to reduce ICT costs, break geographic barriers, and gain access to data at any time and place. A cloud is a factor that puts other SMAC components together.

There have been numerous examples in recent years that show the discrepancy between expectations and the actual benefits that come from the use of ICT tools. The cause of this effect may be the lack of the adequate level of integration between implemented systems. The key to success with the SMAC technology is the combination of the above-mentioned four technologies that communicate and thus provide the economies of scale. None of the four technologies alone can give a full effect. Only the synergy created by all SMAC elements working together makes it possible to create a competitive advantage. So far, organizations have invested in mobility, cloud, business analytics, and the use of social media in business by creating independent and usually incompatible solutions. Their combination within the third platform makes it possible to create new services that generate incomes, deepen relationships with customers, and improve the efficiency of organization operations.

Owing to the development of the computing cloud and the mobile technology, it has been possible to move from closed communication systems to social platforms (Barry 2013, p. 45; Magnier-Watanabe 2009, p. 58). As a result, the work system and business communication have been changed deeply and permanently. Social channels make it possible to create and give access to content quickly, distribute information on a larger scale, and to cooperate and interact with customers better. Mobile technologies have given easier access to information with non-stop online connectivity. Data analyses are used to optimise customer relationship management and improve sales channel efficiency. A cloud, on the other hand, is the foundation of ICT systems in many enterprises, improving their flexibility, scalability, and cost savings of data processing. Organizations that want to maintain their position on a competitive market have to be ready to provide customers with tailor-made services. Owing to the SMAC development, IT technologies are not only the support in business development, but in fact a turning point that gives an advantage to organizations and enables them to 
stand out against the competition. SMAC provides the required information on time, which makes it possible to take right decisions and cooperate effectively both inside and outside an organization, i.e. in the whole cooperation chain.

The unique ICT-ecosystem in intelligent organizations is usually based on advanced ERP class solutions (Enterprise Resource Planning). Traditionally understood ERP systems as a solution that integrates the ICT infrastructure of an organization is no longer sufficient. Their basic functionality has been enriched with CRM systems (Customer Relationship Management), SRM systems (Supplier Relationship Management), SCM systems (Supply Chain Management), and PLM systems (Product Lifecycle Management). Owing to their features, SMAC systems enable enterprises to enhance the efficiency of IT services of business processes and, as a consequence, to improve their competitive position. It can be ventured to say that such solutions are no longer a method of gaining a competitive advantage for businesses, but have in fact become a decisive factor in maintaining their position on the global market.

New ICT technologies, e.g. in the scope of automatic identification, wireless communication, satellite localization or Internet of Things are facing a new challenge. The Internet of Things is a concept according to which unambiguously identifiable items may indirectly or directly gather, process, or exchange data via a global network. Such items comprise, for example, household appliances, lighting and heating installations. The term was used for the very first time in 1999 by Kevin Ashton and since then it has undergone quite an evolution. It is sometimes applied interchangeably with a term "Internet of everything", which describes a network of people, processes, data and intelligent connected to the Internet. The term was created by CISCO Company and has been currently replaced by a term "Internet of Things" (Höller 2014, p. 55; Vongsingthong 2014, p. 99).

Over the last fifty years, ICT has been subject to two key transformations. The first one took place in 1960s and 1970s together with the appearance of solutions supporting automatization of processes, designing (CAD) and manufacturing resource planning (MRP II). The second transformation was the result of the emergence of the Internet and associated solutions. It is assumed that the Internet of Things shall be a driving force of the third wave of changes.

The Internet of intelligent is such a popular concept that it leaves much room for interpretation. The term can be used to describe any unambiguously identifiable thing able to - indirectly or directly - gather and process data. The number of such devices grows dramatically together with the number of possible applications. The Internet of intelligent is closely associated 
with the big data area - as its largest benefit is the efficient gathering and processing of large amounts of information (Perera 2015, p. 142). Three features distinguishing the Internet of Things comprise context, ubiquity and optimization. The first one refers to the possibility of advanced interaction between the item and its surroundings, immediate response to the changes, etc. Under this feature, the items provide information on, for example, location, physical or weather conditions. Ubiquity corresponds to the fact that today there are more things of this kind (items, objects) than people connected to the network. In the near future they will communicate with each other on a large scale. Optimization stands for functionality of each thing (item, object).

The Internet of Things is a concept that is both fashionable and leaves large space for interpretation. This term can be used to describe in fact each and every explicitly identifiable object that is capable of, directly or indirectly, collecting and processing data. The number of such devices keeps growing dramatically, likewise the number of their potential uses. The big data area is closely related to this solution, as the effective collection and processing of large volumes of information are among the greatest benefits offered by IoT (Höller 2014, p. 123).

Three characteristics that distinguish the Internet of Things are context, omnipresence, and optimization. The first quality refers to the possibility of advanced interaction between a thing and the environment and its immediate reaction to changes, etc. Within this characteristic, things supply information, e.g. about localization, the physical status or atmospheric conditions. The omnipresence reflects the fact that already today the number of things (objects) is greater than the number of people connected to the global network. In the near future, they will communicate on a large scale. Optimization is the expression of functionality that is brought by each and every thing (object). Owing to the spread of Internet of Things, such solutions are becoming an integral part of each and every product. Sensors, processors, and their specialist software are integrated into their functionality (they in fact become their sine qua non condition) and are combined with the advanced data analysis. This leads directly to the creation of new and improved products (services), which enables the visible jump in economic efficiency (Perera 2015, p. 165).

According to the IDC forecasts, in the next two years $80 \%$ global businesses will initiate digital transformation projects in knowledge management based on SMAC systems, with 50\% spending related to the third ICT platform solutions (Report IDC 2016, p. 37). According to research conducted by the 
author ${ }^{1}$, the popularity of IT support for management processes in specific SME areas can be presented as follows (percentage of studied enterprises) (Adamczewski 2015, p. 11):

- finance and accounting - 82\%,

- human resources $-71 \%$,

- warehouse management $-58 \%$,

- production management $-19 \%$,

- customer relationship management - $49 \%$,

- office work support - 93\% (including 98\% e-mail),

- purchase and sale process services - $54 \%$.

As regards the use of SMAC solutions, domestic statistics reflect the general global trends in this respect, i.e. (Report IDC 2016, p. 39):

- cloud - is used by $18 \%$ organizations (with $38 \%$ studied population having a plan to launch it),

- mobility - is used by $29 \%$ organizations (with $15 \%$ studied population having a plan to launch it),

- analytics - is used by $9 \%$ organizations (with 16\% studied population having a plan to launch it), and

- social media - declared use by as many as $45 \%$ Polish organizations, and its planned use is forecast at $55 \%$.

The development trends of the Polish IO in the digital transformation are supplemented with the declared innovation initiatives in improving the organization management methods, see (Report IDC 2016, p. 77):

- office digitization - 70\%,

- ICT infrastructure modernization - $64 \%$,

- the consolidation within IT and advanced analytics - $49 \%$,

- new mobile applications for the personnel $-49 \%$,

- team work- $49 \%$,

- mobile self-service applications for customers - 30\%.

Hence, Polish modern business organizations are becoming more confident in using advanced solutions of SMAC systems. The growing demands of intelligent organizations for IT support of knowledge management result generally from their operation in real time (RTE - Real Time Enterprise). Therefore, SMAC systems make it possible to raise the efficiency of management to a higher level through:

1 Conducted in 2014-2015 on a selected sample of 100 enterprises from the SME sector in the Mazowieckie and Wielkopolskie rovinces. 
- reaching customers more effectively with mobile solutions,

- the better understanding of customers' needs with highly processed analytical systems,

- the more effective customer communication with social media,

- the reduced data processing costs with cloud solutions.

The solutions of the third ICT platform together with the Internet of Things technologies are contributing to the quality development of the Polish economy. The use of advanced systems in this respect is becoming not only the requirement for the effective competition of organizations on the global markets but in fact a challenge to be treated as equal of leading global firms.

\section{Conclusions}

In the Polish reality, economic transformations and the evolution of business relationships result in the devaluation of the traditional sources of competitive advantages such as capital, infrastructure, access to sales markets, or the quality of offered products and services. Intelligent organizations that want to compete effectively on global markets have to attach critical importance to their flexibility and the capacity to implement an innovative business model and process reorganizations. Examples of great many Polish firms show that the vision of a business that is managed in a modern way has entered the phase of dynamic implementation, and the effective knowledge management has become a paradigm. There is no doubt that reserves still available in organizations can be drawn on, owing to the support of business operation with advanced ICT systems, where SMAC systems play a crucial role in knowledge management. The present digital transformation will affect the efficiency and operation of business organizations and the economy on the global scale. According to IDC forecasts, until $202060 \%$ businesses will have doubled their productivity owing to the digital transformation of the main operational processes, and by 2019 more than $10 \%$ work resources in developed market economies will have been based on the sharing economy and free agent networks, where decisive solutions will be the third ICT platform systems (Report IDC 2016, p. 77). SMAC technologies feature much higher added value when used jointly. They are even more valuable when integrated with the ICT infrastructure of an organization, and primarily with its business processes. Digital transformation leaders are aware that the key is not so much to select individual technologies but to integrate them completely, to enable the use of the third ICT platform potential. It is worth emphasizing that according to the present implementation experiences, the digital transformation

ICT solutions in intelligent organizations as challenges in a knowledge economy 
is not another marketing slogan but rather a process that gives tangible business benefits.

\section{Summary}

ICT solutions in intelligent organizations as challenges in a knowledge economy

Solutions of the Information and Communication Technology (ICT) are the foundation of modern economic organizations in a knowledge economy. This is the case in particular in intelligent organizations, for which the advanced ICT infrastructure is the sine qua non condition for the effective knowledge management. This article is aimed at describing the role of modern ICT trends, which are described as SMAC, (Social, Mobility, Analytics, (loud), and are becoming an essential ICT element supporting management processes. Such solutions enable to create new models of organization operations on the global markets using strategic resources, such as the knowledge supported with SMAC solutions. The arguments are illustrated with results of own research conducted by the author in 2014-2016 in selected SME's from the Mazowieckie and Wielkopolskie rovinces and their reference to the general development trends in this area.

Keywords: ICT, intelligent organization, knowledge economy, SMAC, SME.

\section{Streszczenie}

Rozwiązania ICT w organizacjach inteligentnych jako wyzwanie gospodarki opartej na wiedzy

Rozwiązania ICT (Information and Communication Technology) stanowią podstawę nowoczesnych organizacji gospodarczych. W szczególności dotyczy to organizacji inteligentnych, dla których zaawansowana infrastruktura teleinformatyczna jest warunkiem sine qua non sprawnego zarządzania wiedzą. Celem artykułu jest ukazanie trendów rozwojowych ICT określanych mianem SMAC (Social, Mobility, Analytics, Cloud), a stanowiących aktualnie kanon informatycznego wspomagania procesów zarządzania w ramach tzw. trzeciej platformy informatycznej. Rozwiązania te pozwalają tworzyć nowe modele funkcjonowania organizacji na rynkach globalnych z wykorzystaniem strategicznych zasobów, jakimi jest 
wiedza wspomagana rozwiązaniami SMAC. Rozważania zostały zilustrowanewynikamibadańwłasnychautora przeprowadzonych w okresie 2014-15 w wybranych przedsiębiorstwach sektora MSP województw mazowieckiego i wielkopolskiego i odniesienie ich od ogólnych tendencji rozwojowych w tym zakresie.

\section{Słowa}

kluczowe: gospodarka oparta na wiedzy, ICT, MSP, organizacja inteligentna, SMAC.

\section{References}

1. Adamczewski P. (2015), Polish SMEs as Intelligent Organizations Conditions of the ICT Support, [in:] IT for Practice 2015, Technical University of Ostrava, Ostrava, pp. 7-21.

2. Barry D.K. (2013), Web Services. Service-Oriented Architectures and Cloud Computing, Morgan Kaufmann Publishers, New York.

3. Cisco Global Cloud Index 2013-2018 (2014), Cisco Systems Inc., San Jose.

4. Graham D., Manikas I., Folinas D. (2013), E-logistics and E-Supply Chain management. Applications for Evolving Business, IGI Global, Hershey.

5. Grösser S.N., Zeier R. (Eds.), (2012), Systematic Management for Intelligent Organizations, Springer-Verlag, Berlin Heidelberg.

6. Höller J., Tsiatsis G. (2014), From Machine-to-Machine to the Internet of Things: Introduction to a New Age of Intelligence, Elsevier.

7. Koronios A., Yeoh W. (2010), Critical Success Factors for Business Intelligence Systems, Journal of Computer Information Systems, Spring, Vol. 22, pp. $60-77$.

8. Magnier-Watanabe R., Senoo D. (2009), The Effect of Institutional Pressures on Knowledge Management and the Resulting Innovation, International Journal of Intelligent Enterprise, Volume 1 - Issue 2.

9. Model biznesu. Nowe myślenie strategiczne, (2013), Ed. M. DuczkowskaPiasecka, Difin, Warszawa.

10. Perera Ch., Ranjan R., Wang L., Khan S., Zomaya A. (2015), Privacy of Big Data in the Internet of Things Era, IEEE IT Professional Magazine, PrePrint (Internet of Anything). Retrieved 1 February.

11. Report "Czas na przyspieszenie. Cyfryzacja Gospodarki Polski", (2016), Polityka Insight na zlecenie ThinkTankCyfrowy.pl - access date 15.07.2016.

12. Report IDC FutureScape "Worldwide IT Industry, (2016), Leading Digital Transformation to Scale", New York.

13. Quinn J.B. (2002), Intelligent Enterprise, Free Press, New York.

14. Schwaninger M. (2010), Intelligent Organizations. Powerful Models for Systemic Management, Springer, Heidelberg - New York. 
15. Vongsingthong S., Smanchat S. (2014), Internet of Things: A review of Applications \& Technologies, Suranaree Journal of Science and Technology No. 3., pp. 123-139.

16. Waltz E. (2003), Knowledge Management in the Intelligence Enterprise, Arteh House, Boston. 